\title{
Testing the liberal subject: (in)security, responsibility and 'self-improvement' in the UK citizenship test
}

\author{
Joseph Turner
}

To cite this article: Joseph Turner (2014) Testing the liberal subject: (in)security, responsibility and 'self-improvement' in the UK citizenship test, Citizenship Studies, 18:3-4, 332-348, DOI: 10.1080/13621025.2014.905273

To link to this article: http://dx.doi.org/10.1080/13621025.2014.905273

$$
\begin{aligned}
& \text { (c) } 2014 \text { The Author(s). Published by Taylor \& } \\
& \text { Francis. }
\end{aligned}
$$

\section{曲 Published online: 14 May 2014.}

Submit your article to this journal $\pi$

$$
\text { Ш Article views: } 1000
$$

\section{Q View related articles $\asymp$}

View Crossmark data $\asymp$

Citing articles: 2 View citing articles $₫$ 


\title{
Testing the liberal subject: (in)security, responsibility and 'self-improvement' in the UK citizenship test
}

\author{
Joseph Turner* \\ Department of Politics, University of Sheffield, Sheffield, UK
}

(Received 24 August 2012; final version received 20 May 2013)

\begin{abstract}
The recent debate over the changes to the 'Life in the UK' citizenship test offers another opportunity to reflect on the testing of would-be citizens in liberal democracies. The citizenship test has often been understood as part of the 'strengthening' of national borders: set within a discourse of fears over high levels of migration and the risk to cultural homogeneity. Furthermore, it has been viewed as an illustration of the death of multiculturalism and presented as an illiberal strategy of cultural assimilation. I propose that whilst the notion of 'testing' is built out of fears regarding 'threatening' difference and 'community cohesion', what the UK testing process presents is an explicitly liberal strategy of governing. Drawing on the history of the test, I suggest that it is not purely a mechanism of restriction but that it also relies on strategies of responsibility, empowerment and 'self-improvement'. The citizenship test, alongside other recent border strategies, may be better understood as representing a fascinating nexus between advanced liberal ideas of governing and concerns regarding (in) security. I argue that studying the test in this way offers up vital questions about how community and political membership continues to be shaped in late modernity.
\end{abstract}

Keywords: citizenship; liberalism; governmentality; political community

The introduction of a Citizenship Ceremony dramatises the importance of someone being welcomed and accepted as a fellow citizen into a network of rights and mutual obligations. (Commission on the Future of Multi-Ethnic Britain 2000, 55)

(Ritual is) separating those who have undergone it, not from who have yet to undergo it, but from those who will not undergo it in any sense, and thereby institutionalising a lasting difference between those of whom the rite pertains and to themselves it does not pertain. (Bourdieu 1991, 117)

\section{Citizenship as movement: the regulation of difference}

To analyse the process through which a 'non-citizen' becomes a 'citizen' may be one of the most appropriate ways to investigate the character of political membership in a liberal state. The possibility of this higher level of 'inclusion' is viewed as a hallmark of a pluralistic democracy. It is the liberal character of greeting the stranger and giving them the opportunity to step over the 'threshold' into full citizenship. The regulation of this movement has likewise been a central concern of liberal states. It has, perhaps, been especially important as the imagery of this movement between 'non-citizen' to 'citizen' has always been accompanied with an imagery of dangers - 'penetration', 'infiltration', 'permeation' from the outside (Ahmed 2000; Douglas 2002). It raises questions of what

*Email: joe.turner@sheffield.ac.uk 
differences (linguistic, cultural, racial) can be 'included' or tolerated within the confines of liberal community. Just as this movement raises questions of 'inclusion', it also relates to concerns over what must be 'excluded' or restricted. The event of citizenship acquisition is then replete with the promise of the stranger being treated like 'us', but it also works on another expectation - of the stranger being like 'us'.

It is in the management of this 'inclusion' and 'exclusion' that we find the appearance of the 'Life in the UK' citizenship test. In the authorised narrative surrounding the test's introduction under New Labour (2005) it was suggested that raising the expectations on the 'would-be citizen' could regulate the ambiguities and anxieties of 'inclusion'. In the words of ex-Home Secretary David Blunkett, the test rests on a concern that 'British citizens should play an active role, both economic and political, in our society, and a have a sense of belonging to a wider community' (Home Office 2004, 3). Under this rationale, the test would make the act of 'inclusion' more visible; it celebrated citizenship unashamedly. The discursive register was of 'civic' virtues, 'support' and 'integration'. Similarly, it was based on the fear that those 'strangers' who have taken up British citizenship have not been nearly like 'us' enough.

By asking the would-be citizen to take a test - to prove their worth - against a backdrop of fears over 'civic renewal', 'community cohesion' and 'belonging', we thus find a host of assumptions about how citizenship can be regulated by modern liberal government.

This article seeks to address how the citizenship test in the UK has been situated within this liberal nexus. It suggests that the full capacity of the citizenship test has often been undervalued as a technique of government and regulation. The debate surrounding testing would-be citizens has often been limited by a focus on the internal consistency of liberalism or the concerns raised by the changes to the test's curriculum. I propose here that in viewing the test process as a set of governmental practices, we can better understand how it manifests changing views of political subjectivity, community and insecurity under 'advanced' liberalism (Miller and Rose 2008, 18). Furthermore, the article provides a necessary analysis of how such assessment works as a historical assemblage of ideas and practices. This means focussing on how the testing process works to harness certain aspects of liberal citizenship and, in doing this, provides restrictions and limits to 'inclusion'. I argue that we need to recognise how these relationships were formed historically through certain assumptions surrounding perceptions of disorder but also wider ideas of responsibility and 'self-improvement'.

\subsection{As a liberal enterprise?}

The practices and content of testing 'regimes' vary across European states but in the UK the following is demanded (Blackledge 2009a):

- The applicant must pass through the testing process before they receive full citizen rights (in 2007 this was expanded for those applying for 'Indefinite Leave to Remain' as well).

- The applicant must possess a quantified level of language in either English/Gaelic/ Welsh. The ESOL qualification (English for Speakers of Other Languages) is used as the official criteria. They must also demonstrate knowledge of 'Life in the UK'.

- Language/knowledge is tested in two different routes: The subject must pass a knowledge-based test ('Life in the UK'), which also provides a test of their language skill, or, if the subject's language is assessed as below ESOL level 3, there is an 
alternative option to take an ESOL course with a 'citizenship component' (Han, Starkey, and Green 2010, 63).

- Successful candidates must 'celebrate' the acquisition of citizenship in a civic ceremony where they pledge an 'Oath of Allegiance'.

As citizenship tests specifically act on the 'non-citizen' by asking them to acquire specific knowledge and language skills, some scholars have been concerned that such tests are contrary to liberalism (Carens 2010; Joppke 2007; Van Oers, Ersbll, and Kostakopoulou 2010; Orgad 2010a, 2010b). The implementation of tests in the UK, Holland and Germany has been understood as an intensification of nationalistic strategies (Blackledge 2009a). They are understood as acts which specifically focus on cultural unity and homogeny often in denial of the liberal stress on individual rights and equality (Joppke 2010). Testing regimes have been equally decried as part of the 'death of multiculturalism' in Europe (De Leeuw and Van Wichelen 2012). Furthermore, they have been described as an extension of 'border strengthening' practices which restrict the access of migrants to European states (Ceobanu and Escandell 2011; Eades 2009; Saville 2009). For these scholars, testing noncitizens is contrary to liberal conceptions of 'inclusion'. They see the examination of wouldbe citizens as based on a model of assimilation rather than tolerance where the principles of pluralism, individualism and equality are silenced (Kim 2011). The central question posed by the Robert Schuman Centre in Florence was just this; 'How Liberal are Citizenship Tests?' it asked in a series of working papers (Bauböck and Joppke 2010).

The field of analysis surrounding citizenship tests has often been limited by the assumptions surrounding its potential liberal character. The implication of this focus is that if testing would-be citizens can be justified under principles of liberalism, then it can be considered acceptable (Hansen 2010; Von Koppenfels 2010). In Kiwan's defence of the UK's citizenship test, she proposes that it is vital in 'emphasising the participative nature of citizenship' (2008, 70). Van Oers, Ersbll, and Kostakopoulou (2010) have used a series of liberal values to compare the policy implementation of the UK, German and Dutch tests. The guiding assumption is that if tests can be perceived as conforming to liberal 'standards', then they can be at least accepted, if not positively endorsed. The other side of this field of analysis is that if the citizenship test is seen as failing the liberal 'litmus test' then it becomes disagreeable; it is too exclusory, it is not fit for purpose. This is a view espoused by many prominent thinkers such as Joseph Carens and Christian Joppke (Carens 2010; Joppke 2007, 2010). Tests must be rejected on the grounds of liberalism then. Liberal government does not tolerate practices of exclusion, so the narrative goes (Orgad 2010b).

Other critiques have been quick to focus on the content of citizenship tests. In the UK, much criticism has been levelled at what knowledge the test has examined: The topics covered, the historical, economic and political events narrated in the official material (Van Oers, Ersbll, and Kostakopoulou 2010). This has been expanded to cover issues of 'reliability', 'validity' and 'practicality' of the test (Hargreaves 2010, 111-114). The Conservative-Liberal Democrat coalition government has recently reinvented the 'Life in the UK' test, with a renewed focus on 'British history' and overt patriotic symbolism (more Shakespeare, less 'practical knowledge') (Travis 2012; Guardian 2013; Home Office 2013). The changes to the test also reflect a wider discussion that the previous information for migrants was too esoteric, too irrelevant or not reflective of 'true Britishness' (Sandbrook 2009). In this way, the test has been viewed as a strategy for different political traditions to propose their own renderings of citizenship and community over others. This has been reflected in more nuanced scholarly accounts of how 'identity' is configured and shaped by the state (Blackledge 2009a, 2009b). 
The framing of such debates perhaps broadly undervalues the importance of the citizenship test. Rather than focussing on liberalism as a guiding normative agenda, this article suggests that we view the test (in the UK at least) not only as a liberal but also as an exclusory technique of government. It is not enough to see the test as a device of border strengthening, or an 'illiberal' act, it is perhaps better understood as a liberal mechanism which is able to set limits on tolerance. It does this, I argue, on the very liberal premise of 'inclusive-exclusion' which Agamben $(1998,21)$ has identified. This relies on the notion that features of exclusion are internally consistent with liberalism, not external to it (King 1999; Connolly 1995). Furthermore, this stresses that in any practice of 'inclusion', the idealising of that which can be 'brought in', there is always a link to 'exclusion' (that which must remain 'outside'). Rather than concentrating on the content of the UK citizenship tests (the questions, facts, figures, design, etc.), I think we can better comprehend the various capacities of the test by understanding how they work as a technology of government; that is, as a set of strategies that shape the field of possible action of subjects. In order to investigate the 'testing process' (as there are two routes of assessment), we need to ask what demands this makes of the migrant-subject and on what assumptions and rationalities these demands are based. We should ask questions then of what Foucault called a practice's 'logical necessity' (Foucault 2009, 116).

In seeing the citizenship testing process as a liberal technique of rule, this analysis relies on a central premise made by Foucault that government concerns both coerce tactics and also 'techniques of the self' (2009; Dean 1999; Rose 1993):

Governing people is not a way to force people to do what the governor wants; it is always a versatile equilibrium, with complimentarity and conflicts between techniques which assure coercion and processes through which the self is constructed or modified by himself (Foucault 1993, 204).

This is particularly important as both testing routes ask that subjects be complicit in acts of government. Testing strategies ask for active participation; for subjects to pay, to learn, to 'better' themselves. In doing this, they ask for the migrant-subject to work on themselves; be responsible, to 'improve', do what is necessary. Only in this way can full rights be distributed. It is important to stress that the method used in this article looks at specific elements of the testing process - that is, the mentality or rationale of testing. It does not (and, in this form, cannot) tell the story of a subject's experience of testing.

Whilst the disciplinary and restrictive aspects of the testing process have been previously highlighted, I think we need to view these capacities alongside other prominent mechanisms of self-government and responsibility (Löwenheim and Gazit 2009; De Leeuw and Van Wichelen 2012). This means demonstrating in this article how the test restricts and normalises, but does this as a feature of 'inclusion'. It works to include migrant-subjects by promoting notions of autonomy, self-sufficiency and empowerment; features which appear central to citizenship under advanced liberalism (Larkin 2011; Lemke 2012). It is important to see how the test works to restrict, but how this works by fetishising and making possible certain forms of conduct and behaviour.

In doing this I argue, alongside Blackledge (2009a), that the citizenship test must be situated in a historical analysis of the civil disturbances that took place in the towns of Bradford, Oldham and Burnley in 2001. This means looking at how government reports problematised such incidents through certain assumptions regarding political community, migration and 'active' citizenship. The civil disturbances involved clashes between British citizens, predominantly between 'Asian' and 'White' men and the police (Bagguley and Hussain 2008, 48-63). What became apparent in the government reports 
and responses to such incidents was a conceptual slipping between the presence of longstanding 'minority' communities and recent migrants. This understanding fed into the emergence of certain government practices that aimed to prevent further disorder. Importantly, I suggest that the historic problematisation surrounding these civil disturbances provided part of the rationale for the introduction of the citizenship test (Foucault 2003, 23). Following on from this discussion, I concentrate on the knowledge and rationalities that underpin the technique of testing (which I argue must be seen in the context of the earlier problematisation). However, as I mentioned above, by investigating what demands are placed on subjects by government authorities, by situating the testing process as practice of self government, I do not infer any understanding of how the subject experiences the testing process. My focus in this article is instead on how the programme of testing understands subjects to be 'governable'. More specifically, I examine how subjects of the test are understood in relationship to a certain ideal of citizenship and how this relies on a certain vision of political subjectivity and community.

\section{A brief history}

The introduction of a citizenship test in the UK did not appear in isolation but, as Etzioni (2007) has remarked, must be seen as part of a wider trend in liberal states - mainly in Europe, North America and Australia. Whilst this is important, I think there are some specific historical conditions in the UK which shaped the policy. The specific issue of 'citizenship' gained government attention after New Labour came to power in 1997. Under both Home Secretaries Jack Straw and then David Blunkett, citizenship explicitly became part of New Labour's plan to resurrect the assumed balance of communitarian rights and responsibilities which were seen as lost under Thatcherism (Blair 1998, 4). This led to the adoption of citizenship lessons for all schoolchildren through changes to the national curriculum (Citizenship Advisory Commission 1998). The discourse also played into the reform of welfare rights - namely the New Deal, which renegotiated relations between welfare claimants and the authorities. These various strategies were voiced in a language of 'communities', 'empowerment' and 'responsibility' (Blair 1998; Etzioni 1995; Giddens 1998).

At first this new assertion of citizenship was couched in universal terms, but it soon became apparent that the targets of such strategies were certain 'problematic' subjects. The visibility of certain 'problem' groups was highlighted in the first report by the Citizenship Advisory Team which took youth malaise, subcultural loyalty and migration as factors which might lead to a democratically disenfranchised generation ('an entire generation has opted out of party politics', it claimed) (Citizenship Advisory Commission 1998, 17). After civil disturbances occurred in the northern towns of Bradford, Oldham and Burnley in 2001, the object of these concerns became increasingly visible. This visibility was linked to the imminent risk of violence and tied explicitly to a discourse of migration/excessive diversity.

The framing of these civil disturbances by numerous analysts and governmental agents becomes important here. As I have suggested, the sporadic violence which occurred in these towns between 'Asian' and 'White' men and the police can be considered as a site of historical problematisation. In the later government White Paper Secure Border, Safe Havens, it became apparent that this disorder and its attributed 'causes' were viewed as set of problems for which the citizenship test became one of the solutions (Home Office 2002a). It is important to recognise the way these events were understood by the 
authorities and how certain 'problems' relating to the existence of long-standing minority communities became linked to the 'problem' of newly arrived migrants. Such a conceptual slippage drew attention to certain differences (predominantly linguistic and cultural) within UK society which were understood to be 'incompatible' with a unified, national and expressively civic rendering of citizenship.

In the wake of the disturbances, the Independent Community Cohesion Review Team (2001) produced a report (commonly known as 'The Cantle Report') which specifically tied together the causes of this violence to both fears over civic degradation and the visibility of linguistic, cultural and racial differences (Radcliffe 2012). What the Cantle Report revealed was a 'vivid picture of fractured and divided communities' that brought with it the imminent possibility of violence (Home Office 2002a, 10). In line with this, the report promoted a common identity - a re-evaluation of values - that could be shared across and within such 'diverse cultural communities' (Independent Community Cohesion Review Team 2001, 15). UK society had become too polarised around 'community differences', so the report went, and this produced disorder itself. For the protection of 'true' community (order, harmony, homogeny), this needed active amendment. So this focus on a lack of 'community cohesion' suggested that both communities involved in the violence ('Asian' and 'White') had to conform around principles of commonality and sameness linked to an understanding of the nation. As the report (Cantle 2001 cited Burnett 2004, 10) suggested:

A meaningful concept of citizenship needs establishing - and championing - which recognises (in education programmes in particular) the contribution of all cultures to this Nation's development throughout its history, but establishes a clear primary loyalty to this Nation.

It is this 'meaningful concept of citizenship' that was taken up by policy makers working on the Secure Borders White Paper (Home Office 2002a). It was in this document that we find the link between the civil disturbances and the implementation of the citizenship test. Importantly, the violent nature of the disturbances in northern towns provided an example of the 'necessity' to foster 'community cohesion' on a national scale. Such evidence was further enhanced by the post-September 11 climate of insecurity. The potential involvement of UK citizens in Al-Qaeda networks strengthened the authorities' focus on minority communities, 'migrant-citizens' as well as newly arrived migrants (Greenwood and Robins 2002, 506).

Whilst the disorder in northern towns may have concerned 'settled' communities, 'Asian' communities were frequently perceived as possessing traits which linked them to the 'outside', to the transgression of both the territorial border and citizenship. 'Fractured communities', which held the potential for future disorder, were depicted as the product of class differences, poverty but also migration because of the persistence of certain traits (linguistic, cultural and racial) which migrant-citizens were understood to hold (Home Office 2002a, 10). Again, the Secure Borders document made this leap explicit. The report began by suggesting that 'The first challenge migration poses is to our concept of national identity and citizenship' (Home Office 2002a, 9). This contextualised the direct link to the civil disturbances and the findings of The Cantle Report that 'painted a vivid image of fractured and divided communities, lacking a sense of common values or shared civic identity to unite around' (Home Office 2002a, 10). As Tomlinson observed, there was an important conflation here between 'the presence of long-standing minority citizens with newer migrants and refugees' - those seeking abode and rights $(2008,135)$. This visibility of migrant-subjects continued as the report turned to the key solutions to such problems 
and its fostering of civic and 'common' values around which citizenship could flourish (Fortier 2008).

Whilst the Cantle Report suggested numerous strategies to foster 'community cohesion', the Secure Borders document proposed that the acquisition of citizenship (the movement from 'outside' to 'inside') was a principal area where this could be managed. 'Inclusion' into citizenship was a problem, one that troubled 'confident identity', but it was also perceived as a site of opportunity where government forces could bring 'active' change (Home Office 2002a, 9). Within this context, a citizenship test was heralded as a mechanism which could foster and develop this necessary 'cohesion'. As was suggested in the White paper (Home Office 2002a, 11):

The acquisition of British Nationality is a bureaucratic exercise, with almost no effort made to engage new members of the community with the fundamentals of our democracy and society ... In an increasingly diverse world it is vital that we strengthen both our sense of community belonging and civic and political dimensions of British citizenship. In particular, we intend to offer language training and light touch education for citizenship for those making a home in the UK - with a view to simple examination for citizenship applicants similar to that which exists in other countries. This will strengthen the ability of new citizens to participate actively in our democracy. This will help people understand both their rights and obligations as citizens in the UK, and strengthen the bonds of mutual understanding between people of diverse backgrounds. It will also help promote individuals' economic and social integration.

The report provided a number of dynamics and processes which became etched into the institutionalisation of the testing process (through the Nationality and Immigration and Asylum Act 2002). Whilst such a strategy was pursued in the name of all ('community cohesion', civic values, democracy), it targeted the citizenship-seeking migrant as the visible problem in need of supportive government. The would-be citizen was viewed as a risk to 'cohesion', but a risk that could be mitigated through empowerment; 'strengthen(ing) the ability of new citizens to participate actively in our democracy'. In this vision the individual subject was seen as the site of potential change. The logic of the test was to act on the subject but through 'engagement'/'light touch'. It was about supporting and 'helping' the individual to reach their potential (their 'economic and social integration'), namely through education. This was balanced with a stress on 'civic' values, and multicultural tolerance: '(the) bonds of mutual understanding between people of diverse backgrounds'. In the inception of the test, old tropes (like the focus on the unifying and symbolic quality of the English language) blended with new models of civic citizenship, pluralism and notions of individual responsibility. The citizenship test was after all proposed as a model of 'Integration with Diversity' (Home Office 2002a).

The Nationality and Immigrant and Asylum Act 2002 then enforced such provisions by pushing forward the recommendations found in the White Paper. The regime of testing was offered as a central technocratic practice through which the various necessary and essential 'common values' of citizenship could be performed and structured. It could 'animate and give moral content to the benefits and duties of citizenship to which new entrants aspire' (Home Office 2002a, 9). This meant that after 2005, all applicants of naturalisation would either need to attend an ESOL and citizenship course or pass the 'Life in the UK' test. The test (and the course materials for learners) was originally constructed out of the recommendations of the 'Life in the UK' Advisory Team and included categories on health, economy, education - its primary focus was 'practical knowledge' (Home Office 2002a, 2004; Department for Education and Skills and the Home Office 2010). In the most recent changes to the content of the test (2013), such a focus on 'practical knowledge' has been overturned with an emphasis on information relating to 
'identity, culture and history' (Hogenboom 2013). Through either route, after 2005, any applicant of naturalisation has had to possess enough knowledge needed to 'settle' and 'integrate' into the political community. Central to the new acquisition of citizenship was also the introduction of a citizenship ceremony. This practice acts as a symbolic setting where new citizens are required to pledge an 'Oath of Allegiance'. This was intended as part ritualised celebration, part confirmation of the boundaries (cultural and civic) the new migrant was stepping into.

\section{Restriction, discipline and responsibility: understanding the liberal nexus of the test}

What these practices offer is a way of working on the migrant-subject before citizenship is acquired. This is a marked change from older 'integration' and 'assimilatory' strategies that previously took the new citizen (not the would-be citizen) as their central referent. By creating a testing process which focuses on both language and knowledge, certain differences are notably categorised and acted upon over others. This arguably changes access into citizenship as it became more restrictive for certain candidates. It is no longer an expectation that the migrant-citizens may learn English or, likewise, may gain knowledge from spontaneous engagement with wider society (socialisation, etc.), it becomes something that must be imposed, mandated and 'supported'. It is something that must be examined and regimented by state mechanisms. Importantly, whilst the authorities set the parameters for this examination, it is the individual subject who must learn, overcome the impediments and develop through this process. They must be 'helped to help themselves' (Cruikshank 1999, 4).

We then see different dynamics at play here which converge around a certain accepted vision of modern liberal citizenship. This does not necessarily imply any 'hidden' intentionality on behalf of government authorities here, or a schema of total coherence. Instead, I want to suggest that there are some fundamental assumptions that flow through the test which converge around certain 'truth' claims regarding political subjectivity and 'ideal' community. The test thus makes possible new devices of restriction through changing the way 'inclusion' is governed. I make this point not just to highlight that governmental strategies have undesired effects and unknown consequences (which they do), but also that practices that are discursively framed to 'empower' and 'better' also create limits; they act to normalise and discipline just as they produce.

\subsection{Learning, self-government and subjectivity}

The test may 'exclude' and restrict, but it does this through the power to 'include'. 'Inclusion' here rests, I argue, on ideas of responsibility, self-improvement and empowerment - key aspects of advanced liberal citizenship. So, certain behaviours and attributes are normalised through the test but this involves the subject partaking actively in these strategies. It is an example of a form of self-government which is crucial to advanced liberal rule (Foucault 1993; Dean 1999; Rose 1993).

The test essentially promotes and makes possible a certain form of 'inclusion' by asking the migrant, would-be citizen, to participate in their own judgement. It understands the application to citizenship to be about proving worth, about providing evidence of sacrifice before rights can be distributed. The authorities must define what this worth and proof will be (language and knowledge of the 'Life in the UK'/ESOL course material), but the burden of this must be carried by the subjects themselves. This 
reveals an important shift of focus. The authorities' decision to grant a subject UK citizenship is no longer purely based on an assessment of criteria (length of settlement, background, relationships, interviews, etc.), instead the subject must act as an active agent within the process. They must now act, learn and participate within a certain set of established strategies. The test shifts the burden of proof of worth onto the migrant-subject and asks them to take up responsibility for at least part of the process. We can thus see the strategy in line with ideas of responsibilisation (Miller and Rose 2008, 77).

\subsection{Responsibility: an economic sacrifice}

The testing strategy works to restrict by privileging certain traits held by subjects (language skills, economic solvency) and at the same time, guides subjects by asking them to show responsibility. As I suggest, it is important to see this shaping of responsibility in line with a certain view of liberal citizenship and subjectivity.

One such responsibility that is demanded in the test is that of an economic sacrifice. The application to gain UK citizenship is itself expensive but the test now demands the purchase of additional support material - provided through private contracts linked to the Home Office (Hargreaves 2010, 107). ${ }^{2}$ This shifts a further financial burden onto the applicant. Alongside a monetary sacrifice, the testing process also demands the sacrifice of personal time, of energy and the need to access resources such as English language classes, courses, etc. (Cooke 2009, 75).

Both assessment routes are based on demonstrating linguistic capability. Whilst the 'Life in the UK' test demands language competency through recognising the questions of the multiple choice test, the ESOL course demands 'relevant progress' in language competence (Han, Starkey and Green 2010, 22; UK Border Agency 2012a, 2012b). This means a subject must possess English/Welsh/Gaelic or must learn or improve their skills. Language courses are often difficult to access and underfunded (Greater London Authority 2012). In 2013, applicants who have refugee status still have formal access to free Englishlanguage lessons but in England, in particular, public funding has been drastically reduced. This means that services are often sporadic, with extensive waiting lists - often of years (Doyle and O'Toole 2013, 12-13; Kiwan 2008). For economic migrants this is even more difficult and expensive to access. As Cooke has highlighted, this essentially means that applicants applying for citizenship (through either ESOL or the test route) must often pay for courses privately, or teach themselves $(2009,75)$. Such activities are more nuanced and involve a more complex arrangement of time, finances and knowledge than previous forms of naturalisation.

The testing process then privileges those who already speak English. This broadly privileges applicants from English-speaking countries. As Groenendijk and Van Oers $(2010,10)$ point out, this is reflected in an almost $100 \%$ pass rate of applicants from North American, Australia and New Zealand. It also works to privilege elite applicants such as highly skilled workers who tend to have access to English and educational opportunities. This privileging of skills and socio-economic capital is compounded by the nature of examination itself, as it requires a certain level of educational merit, literacy and communication skills. This is especially relevant to not only the multiple-choice test with its emphasis on self-learning but also the ESOL course which relies on institutional education (Han, Starkey, and Green 2010). The practice of actually sitting an examination, like learning in a classroom, is something which is normalised within certain cultural and class frameworks (Löwenheim and Gazit 2009). In this way, the strategy works to restrict 
by privileging and elevating specific learnt behaviours. It does this by a set of new economic and social demands that it refocuses.

This strategy actively relies on the subjects taking responsibility for their 'own destiny'; as an act of self-responsibility. The migrant can be 'included' if they can overcome such impediments/challenges that form the testing process. The sacrifice of personal time, money and ability to access resources is supposed to show a sustained level of commitment to the authorities. In this sense, it reminds us of one of the essential logics of the social contract and the type of liberal citizenship it presupposes - the fundamental need for proof of sacrifice for rights to be distributed (Wells 2008, 78). The commitment to get over such challenges can demonstrate that the candidate has earned the 'right to have rights' (Arendt 1958, 296; Schaap 2011). In this way, the meritocracy and privileging endemic to the test is the display of the capacity of the 'good'/'deserving' subject.

What this shift in responsibility reflects, amongst other things, is an emphasis on the unitary character of the individual. By allowing the individual migrant to take on the responsibility and burden of proof, we see the establishment and reiteration of many facets of the autonomous and self-sufficient subject of advanced liberalism (Read 2009; Lemke 2012). The subject (who can be included) becomes defined by what responsibility they can demonstrate.

\subsection{Responsibility: the role of learning}

To further this point, another fundamental responsibility which the test asks is that of active change. It asks that the migrant-subject take up new cultural forms, skills and knowledge so they can be included into the political community. This is premised on a central assumption of self-improvement through the processes of learning which has a value-laden position in liberalism. The subject must reveal their capacity for change in their engagement with the test; they must actively seek to learn English (if necessary) and also learn the facts, figures and normative judgement which are supposed to reflect 'Life in the UK'. In the case of those taking the multiple-choice assessment, they have to reproduce knowledge found in the authorised documents. These authorised documents are tailored to suit personal study and include learning tools such as study guides, practice question and answers, mock tests, study timetables. Equally, those taking ESOL citizenship courses must provide evidence of their 'relevant' progress in language acquisition. Through either route candidates must work upon themselves, they must selfdiscipline, push themselves, harness behaviour and skills to acquire knowledge (of the documents and language) which demonstrates a process of self-development/ improvement.

This reflects the precise point that Foucault made about advanced liberal government and the way that it works on individuals through self-government. He identified something that is key here, that under certain practices: 'Human Beings come to understand and act upon themselves within certain regimes of authority and knowledge, and by means of certain techniques directed to self-improvement' (Rose, O'Malley, and Valverde 2006, 91). It can be suggested that the test works to harness this process. It demands evidential proof of improvement and this proof is located in the actions of the subject. At the same time, the techniques in which this is demonstrated are set and dictated by the authorities. This is the power on which 'inclusion' into citizenship is premised.

Whilst dwelling on this point, we can perhaps suggest that the very practice of learning is more meaningful than what is learnt in the test. The act of learning (in itself) is then a feature of the 'worth' of the would-be citizen. This learning, and the strong normative link 
it has to liberal notions of self-improvement and self-development, reveals how the test asks the subject to at least imitate characteristics that the ideal citizen should possess. It means that they can promise the potential for change; they are malleable, adaptable or at the very least committed. That the 'Life in the UK' test can, in principle, be taken an indefinite amount of times supports this logic: those who are left 'out in the cold' (without full rights) are offered the chance of future self-reform and 'inclusion'.

In this way the notion of responsibility and rights endemic to liberal citizenship is altered slightly in the testing regime. First, responsibility (to learn, to pay, to access resources) is demanded of the subject before rights are distributed. This is reflective of wider changes to the distribution of responsibility and rights in the UK, such as in the government of welfare claimants, but the emphasis here on responsibility preceding rights is perhaps unique to this process (Etzioni 1995; Blair 1998). Second, the would-be citizen does not just learn about the expectation of responsibility, instead, they must actually engage in a strategy of responsibility before they are 'included'. The demand from the authorities to learn, and the participation of the subject in the process of learning, is thus actually the conduct of citizen responsibility. It is thus possible to suggest that the wouldbe citizen must imitate the 'rules of the game' in the testing process before they are allowed to claim rights. As Rose has suggested, what defines the modern, active citizen of advanced liberalism is the push towards continuous 'modulation, adjustment and improvement' $(2001,24)$. This is the goal that the migrant-subject is put towards. This is what I mean by the practice of learning being perhaps greater than what is learnt. It becomes a powerful totem of the 'active' and 'committed' subject who will become a citizen (Honig 2001, 73-75). What migrant-subjects demonstrate in the testing process is the necessary 'active' participation and values that the authorities were so concerned about fostering and developing.

It is important at this point to resituate the role of self-government into the initial problematisation that testing process rests on. The feature of learning implicit in the test makes a claim over the would-be citizen and demands a certain field of action from the subject. The assumption here regarding learning is that it leads to self-betterment and selfimprovement (they will be better 'suited' to life, supposedly have more access to jobs, etc.). This is based on a conceptualisation of the subject as an agent with the capacity to 'better' themselves; imagined as a kind of internal process of self-government (Foucault 1990). In the testing process, the subjects are asked to partake in this process and 'improve' themselves as an individual agent; free and equal before the law. The test is then understood as a facilitating mechanism of a certain form of empowerment. There is a normalising strategy implicit here, in that it asks all subjects of the test to behave in a certain way, it demands that they pick up, take on and show the traits of self-development and 'empower' themselves through self-government. It does this whilst concealing all of the coded and implicit connections this has to certain economic, cultural and social forms of capital - communication skills, access to resources, economic solvency, etc.

This must be seen in the context of the security concerns which emerged after the civil disturbances in 2001, and the discourse of anxiety over community cohesion which The Cantle Report focussed on (re-emphasised in the Secure Borders document). In light of this history it becomes possible to suggest that the act of learning and pre-citizenship responsibility found in the strategy of testing offers a way of working upon the migrantsubject which makes them appear 'safer'. By this I mean that it increases the possibility of 'common' (civic) traits being in possession (the central concern of The Cantle Report and the Secure Borders White Paper). The test works by actively privileging certain traits whilst silencing the differences (those speaking 'other' languages, those unable to 
'develop') which it works upon and restricts. This perhaps reflects one of the central rationales for the testing process; the problematisation of certain differences which created the conditions for 'fractured and divided communities'. Whilst 'diversity' was positively affirmed in government discourse, certain differences possessed by migrants (such as the lack of a common language) were viewed as potential risks to cohesion. As this process was about the promotion of values and language that should be in common possession, the testing process is able to directly question and restrict those without such attributes. This restrictive capacity, although working on all in principle, works on some subjects more than others because the test privileges certain traits. It privileges those who already speak English, who possess knowledge of examination practices, or educational courses, likewise, those who have the economic capacity to afford to take English classes, citizenship materials and test fees. Importantly, it privileges and fosters certain forms of conduct, responsibility, sacrifice and learning. It does this for certain normative ends: Selfimprovement, empowerment and 'community cohesion'. It leaves those who may be too troubling to the margins (those who cannot show 'enough' improvement, those who persist in failing the test) whilst overtly 'including' those who possess acceptable and welcomed traits (shared values, language, economic solvency). It promotes those who possess traits close to the citizen ideal, who may be able to fit within the idealised space of the nation. As Sales (2002) has argued elsewhere, this type of practice is perhaps best described as dividing the 'deserving' from the 'undeserving' migrant-subject.

This strategy is essential to the knowledge and rationalities that the test is built on. Such a privileging is central to the kind of moral subjectivity which is idealised in the language and practices of advanced liberalism. This means that certain ideas of sameness are more readily 'included' into the national space than those possessing certain differences.

\section{The distribution of inclusive-exclusion}

As I have hopefully demonstrated, responsibilising and restrictive strategies in the testing process are not in competition or are contradictory; instead, I consider these expressions of liberal power to be two sides of the same coin. In asking the would-be citizen to perform certain functions (to pay, learn and provide evidence of achievements) before rights are distributed, I argue that the subject of the test is acted upon as a 'risk' - but one that can be modified and made safer through certain techniques of 'inclusion' (self-improvement, education, understanding). In this process certain traits are fetishised (economic solvency, language, behaviour) leading to a form of 'inclusive-exclusion'.

Even if the 'journey' of the migrant into citizenship is actively praised in the testing process (the citizenship ceremony, the idea of cultural tolerance, 'empowerment'), it still relies on the moral economy that they must do more to prove themselves. They must do more than citizens of birthright, essentially because they pose more risk, they bring the potential of disorder through their relationship to the 'outside'/to difference. Those who have proved their 'worth' deserve rights ('inclusion'), but the important thing is that the authorities demand this of the citizenship-seeking subject. It is demanded so that full rights can be distributed to a 'deserving' subject. Equally, this moral economy proposes that this proof must be administered by authorities and actively examined (either in a test centre or by accredited teachers of ESOL); it cannot be left to organic processes, implicit socialisation or proof of other social/communal involvement. The would-be citizen is a site of problems but ones that can be overcome through their own self-development and 'empowerment'. 
This further 'marking' of the migrant-subject and the imposition of responsibility is of course central to the logic/strategy analysed here, and likewise central to the security imperative through which the test is constructed. There is a synthesis then here between the restricting and responsibilising elements of the test which needs highlighting. The power of the test works to 'include' migrant-subjects by operating as a strategy of selfgovernment. In this way applicants are 'brought to work on themselves' as proof of selfimprovement and yet such 'empowerment' is demanded in the name of the wider political community which they are 'entering' (Rabinow and Rose 2006, 197). Such acts of responsibility and improvement are asked for in the name of individual self-worth (employment, socialisation), but ultimately as a greater collective 'good'. This 'good' is the aim of fostering harmonious relations and the maintenance of order (in the shape of 'integration with diversity') within the body politic. In this way, would-be citizens are put to work in the testing process, to better themselves, for the health and security of the political community they are 'entering'.

\section{In conclusion: advanced liberalism, security and inclusive-exclusion}

I have specifically chosen not to focus on the content of the test in this article but instead on the testing process as a series of practices, rationalities and strategies of government. This has meant focussing on how the migrant-subject is governed in the testing process through certain practices of self-government and how this relies upon certain ideas of responsibility, conduct and subjectivity. I have likewise demonstrated how this must be understood in relation to the test's emergence within a set of particular historical events. In order to understand how the test works as a programme of government, it is important to recognise the field of problems it was set to respond to and how various ideas became intermeshed into its institutionalisation.

It has been my purpose in this article to suggest that the testing process works as an interesting set of practices of contemporary government. Understanding how the test works as a inclusive-exclusive mode of liberal government means also recognising the security imperative it was rationalised through. The testing process works as a site where various aspects of advanced liberal citizenship are manifested; self-responsibility, the balance or rights and duties, individualism/autonomy. Likewise, it reveals different ways of imagining and regulating political community; the emphasis on 'shared values', behaviour and the 'inclusion' of those migrant-subjects that have proved their 'worth'. As I have demonstrated, this always works in relation to the changing forms of restriction which hold back and potentially 'exclude' other subjects.

In summary, the programme and technique of testing changes the way that inclusion is practiced in the UK. This means that after the analysis of civil disturbances in 2001 and through the frame of 'community cohesion', there has been a refreshed need to provide a set of mechanisms that alter how inclusion into citizenship is performed. The testing process can adjudicate inclusion by producing a number of restrictions. It does this by categorising those who can pass and those who cannot (and those who cannot even apply). It can be said to work on certain differences which are 'too great' to be tolerated (those who cannot speak English/Gaelic/Welsh, those who are unable to show a satisfactory level of improvement, who cannot/will not learn or 'self-improve'). It does this by privileging certain traits held by some subjects and not others. The practices of testing work on certain forms of difference, essentially as a series of normalising strategies which ask the migrantsubject to conform to a certain set of behaviours and processes. Through the acquisition of both language skills and cultural knowledge - the reification of a Janus-faced 'tolerant' 
but equally unified 'common identity' - the migrant is expected to become more like a certain vision of the ideal citizen. They must do this so as to be 'included' and be given access to rights, or persist to remain 'outside'.

As I have suggested, this process of regulation is tied to certain strategies of government which rely upon responsibility and empowerment as ways of managing subjects. This relies on the more productive side of the power dynamic that Foucault identified in modern forms of control (Foucault 1991, 1998). By this, I mean to suggest that the test envisages a migrant-subject who must become active in the citizenship application process. In this sense, the emphasis is put on the migrants to prove themselves in the process. Furthermore, this understands that certain differences that the migrant may hold can be 'overcome', or at least bettered, through the liberal faith in self-improvement and education. Thus, the site of power is not just the mechanism of the test - the legislation, the test centre, the authorised documents - but power also constitutes the action of the subject as an individual. They must act as a singular agent to overcome the impediments put in front of them - to learn, to pay, to prove themselves. The role of government is to provide the conditions through which the migrants are able to prove themselves 'worthy'/'deserving'. In this sense the test is perhaps an example of advanced liberal subjectification with its emphasis on self-responsibility and moral agency (what it asks of the subject) (Larkin 2011).

In this way the testing process works on the migrant through the premise of security concerns that are central to the functions of governmentality. It works as a series of practices which act on differences through the parameters which are put on inclusion. The testing process guides subjects towards certain forms of conduct; responsibility, commitment and self-improvement - behaviours which are important aspects of citizenship under advanced liberalism. In this powerful mode of inclusive-exclusion, the new would-be citizen who wishes to transgress the boundary of citizenship must still act like us before they are welcomed over the threshold. The historical problematisation which made the test possible provided new and complex ways in which certain differences became an object of security concerns. It made certain differences appear troubling in the discourse of 'community cohesion'. The testing process has provided new strategies for acting upon them.

\section{Acknowledgements}

I would like to thank Martin Smith and Inanna Hamati-Ataya for their comments on drafts of this article and the constructive feedback of two anonymous reviewers.

\section{Funding}

This research was funded by the Economic and Social Research Council +3 studentship.

\section{Notes}

1. There are a number of pledges. The primary 'Oath of Allegiance' being: 'I (name) swear by Almighty God that on becoming a British citizen, I will be faithful and bear true allegiance to Her Majesty Queen Elizabeth the Second, her Heirs and Successors, according to law'. Variations are displayed on the UK Border Agency website (2012a, 2012b).

2. A private (not-for-profit) organisation is currently contracted to run the test Ufi Limited (http:// www.uficharitabletrust.org/). The test costs $£ 50$. The application fee for naturalisation is $£ 851$ for an adult. 


\section{References}

Agamben, Gorgio. 1998. Homo Sacer: Sovereign Power and Bare Life. Stanford, CA: Stanford University Press.

Ahmed, Sara. 2000. Strange Encounters: Embodied Others in Post-Coloniality. London: Routledge. Arendt, Hannah. 1958. The Origins of Totalitarianism. 2nd ed. London: George Allen and Unwin. Bagguley, Paul, and Yasmin Hussain. 2008. Riotous Citizens: Ethnic Conflict in Multicultural Britain. Aldershot: Ashgate.

Bauböck, Rainer, and Christian Joppke, eds. 2010. How Liberal are Citizenship Tests? EUI Working Papers RSCAS 2010/41. Florence: Robert Schuman Centre for Advanced Studies.

Blackledge, Adrian. 2009a. "Inventing English as Convenient Fiction: Language Testing Regimes in the United Kingdom." In Language Testing, Migration and Citizenship: Cross-National Perspectives, edited by G. Extra, M. Spotti, and P. Van Avermaet, 65-85. London: Continuum. Blackledge, Adrian. 2009b. “'As a Country We Do Expect': The Further Extension of Language Testing Regimes in the United Kingdom." Language Assessment Quarterly 6 (1): 6-16.

Blair, Tony. 1998. The Third Way: New Politics for a New Century. London: The Fabian Society. Bourdieu, Pierre. 1991. Language and Symbolic Power. Cambridge: Polity.

Burnett, Jonathan. 2004. "Community, Cohesion and the State." Race and Class 45 (3): 1-18.

Carens, Joseph. 2010. "The Most Liberal Citizenship Test is None at All." In How Liberal are Citizenship Tests? EUI Working Papers RSCAS 2010/41, edited by Rainer Bauböck and Christian Joppke, 19-21. Florence: Robert Schuman Centre for Advanced Studies.

Ceobanu, Alin, and Xavier Escandell. 2011. "Paths to Citizenship? Public Views on the Extension of Rights to Legal and Second Generation Immigrants in Europe." British Journal of Sociology 62 (2): $221-240$.

Citizenship Advisory Commission. 1998. Education for Citizenship: Teaching Democracy in Schools. London: Qualification and Curriculum Authority.

Commission on the Future of Multi-Ethnic Britain. 2000. The Parekh Report: The Future of MultiEthnic Britain: Report of the Commission on the Future of Multi-Ethnic Britain. London: Profile Books.

Connolly, William. 1995. The Ethos of Pluralization. Minneapolis: University of Minnesota Press.

Cooke, Melanie. 2009. "Barrier or Entitlement? The Language and Citizenship Agenda in the United Kingdom." Language Assessment 6: 71-77.

Cruikshank, Barbara. 1999. The Will to Empower: Democratic Citizens and Other Subjects. New York: Cornell University Press.

Dean, Mitchell. 1999. Governmentality: Power and Rule in Modern Society. Thousand Oaks, CA: Sage.

De Leeuw, Marc, and Sonja Van Wichelen. 2012. "Civilising Migrants: Integration, Culture and Citizenship." European Journal of Cultural Studies 15 (2): 195-210.

Department for Education and Skills and the Home Office. 2010. Citizenship Materials for ESOL Learners. Leicester: NIACE.

Douglas, Mary. 2002. Purity and Danger: An Analysis of Pollution and Taboo. London: Routledge.

Doyle, Lisa, and Gill O’Toole. January 2013. "A Lot to Learn: Refugees, Asylum Seekers and Post 16 Learning. Refugee Council Report.” Refugee Council. http://www.refugeecouncil.org.uk/ass ets/0002/5956/A_lot_to_learn-Jan_13.pdf.

Eades, Diana. 2009. "Testing the Claims of Asylum Seekers: The Role of Language Analysis." Language Assessment Quarterly 6 (1): 30-40.

Etzioni, Amitai. 1995. The Spirit of Community: Rights, Responsibilities and the Communitarian Agenda. London: Fontana.

Etzioni, Amitai. 2007. "Citizenship Tests: A Comparative, Communitarian Perspective." The Political Quarterly 78 (3): 353-363.

Fortier, Anne-Marie. 2008. Multicultural Horizons: Diversity and the Limits of the Civil Nation. Oxon: Routledge.

Foucault, Michel. 1990. The Care of the Self: The History of Sexuality, Volume 3. New York: Penguin.

Foucault, Michel. 1991. Discipline and Punish: The Birth of the Prison. London: Penguin.

Foucault, Michel. 1993. "About the Beginning of the Hermeneutics of the Self: Two lectures at Darthmouth.” Political Theory 21 (2): 198-227.

Foucault, Michel. 1998. The Will to Knowledge: The History of Sexuality, Volume 1. London: Penguin. 
Foucault, Michel. 2003. "Polemics, Politics, Problematisations: An Interview with Michel Foucault." In The Essential Foucault: Selections from Essential Works of Foucault, 1954-1984, edited by Paul Rabinow and Nicholas Rose, 18-25. New York: The New Press.

Foucault, Michel. 2009. Security, Territory and Populations: Lectures at the Collège De France. Basingstoke: Palgrave.

Giddens, Anthony. 1998. The Third Way: The Renewal of Social Democracy. London: Polity.

Greater London Authority. 2012. Analysis of English Language Support Provision in London for JSA and ESA WRAG Customers. London: Greater London Authority.

Greenwood, John, and Lynton Robins. 2002. "Citizenship Tests and Education: Embedding a Concept." Parliamentary Affairs 55: 505-522.

Groenendijk, Kees, and RickyVan Oers. 2010. "How Liberal Tests Are Does Not Merely Depend on Their Content, But Also Their Effects." In How Liberal are Citizenship Tests? EUI Working Papers RSCAS 2010/41, edited by Rainer Bauböck and Christian Joppke, 9-11. Florence: Robert Schuman Centre for Advanced Studies.

Guardian. 2013. "British Citizenship Test: Values and Principles of the UK." The Guardian [online], 27 January. Accessed March 6, 2013. http://www.guardian.co.uk/uk/interactive/2013/jan/27/ british-citizenship-test-values-principles.

Han, Christine, Hugh Starkey, and Andy Green. 2010. "The Politics of ESOL (English for Speakers of Other Languages): Implications for Citizenship and Social Justice." International Journal of Lifelong Education 29 (1): 63-76.

Hansen, Randell. 2010. "Citizenship an Unapologetic Defence." In How Liberal are Citizenship Tests? EUI Working Papers RSCAS 2010/41, edited by Rainer Bauböck and Christian Joppke, 25-29. Florence: Robert Schuman Centre for Advanced Studies.

Hargreaves, Marian. 2010. "Citizenship Testing in Anglophone Countries: The UK, Canada and the USA.” In From Migrant to Citizen: Testing Language, Testing Culture, edited by C. Slade and M. Möllering. London: Palgrave Macmillan.

Hogenboom, Melissa. 2013. "What History Should Be in the UK Citizenship Test?" BBC News [online], 29 January. Accessed May 5, 2013. http://www.bbc.co.uk/news/magazine-21234254.

Home Office. 2002a. Secure Borders, Safe Havens: Integration with Diversity in Modern Britain. London: HMSO.

Home Office. 2002b. The New and the Old: The Report of the "Life in the United Kingdom" Advisory Group. London: HMSO.

Home Office. 2004. Life in the United Kingdom: A Journey to Citizenship. London: HMSO.

Home Office. 2013. Life in the United Kingdom: A Guide for New Residents. London: HMSO.

Honig, Bonnie. 2001. Democracy and the Foreigner. Princeton, NJ: Princeton University Press.

Independent Community Cohesion Review Team. 2001. Community Cohesion: Report of the Independent Review Team (The Cantle Report). London: Home Office.

Joppke, Christian. 2007. "Beyond National Models: Civic Integration Policies for Immigrants in Western Europe." West European Politics 30 (1): 1-22.

Kim, Nam-Kook. 2011. "Deliberative Multiculturalism in New Labour's Britain." Citizenship Studies 15 (1): 125-144.

King, Desmond. 1999. In the Name of Liberalism: Illiberal Social Policy in the United States and Britain. Oxford: Oxford University Press.

Kiwan, Dina. 2008. "A Journey to Citizenship in the United Kingdom." International Journal on Multicultural Societies 10 (1): 60-75.

Larkin, Philip M. 2011. 'Incapacity, the Labour Market and Social Security: Coercion into 'Positive' Citizenship." The Modern Law Review 74 (3): 385-409.

Lemke, Thomas. 2012. Foucault, Governmentality and Critique. Boulder, CO: Paradigm.

Löwenheim, Oded, and Orit Gazit. 2009. "Power and Examination: A Critique of Citizenship Tests." Security Dialogue 40 (2): 145-167.

Miller, Peter, and Nicholas Rose. 2008. Governing the Present. Cambridge: Polity.

Nationality, Immigration and Asylum Act 2002, (c. 41). http://www.legislation.gov.uk/ukpga/2002/41.

Orgad, Liav. 2010a. "Five Liberal Concerns About Citizenship Tests." In How Liberal are Citizenship Tests? EUI Working Papers RSCAS 2010/41, edited by Rainer Bauböck and Christian Joppke, 21-25. Florence: Robert Schuman Centre for Advanced Studies.

Orgad, Liav. 2010b. "Illiberal Liberalism Cultural Restrictions on Migration and Access to Citizenship in Europe." The American Journal of Comparative Law 58: 53-106.

Rabinow, Paul, and Nicholas Rose. 2006. "Biopower Today." Biosocieties 1: 195-217. 
Radcliffe, Peter. 2012. "Community Cohesion: Reflections on a Flawed Paradigm." Critical Social Policy 32 (2): 262-281.

Read, Julian. 2009. "A Genealogy of Homo-Economicus: Neoliberalism and the Production of Subjectivity." Foucault Studies 6: 25-36.

Rose, Nicholas. 1993. "Government, Authority and Expertise in Advanced Liberalism." Economy and Society 22 (3): 283-299.

Rose, Nicholas. 2001. "Normality and Pathology in a Biological Age." Outlines 1: 24-33.

Rose, Nicholas, Pat O'Malley, and Mariana Valverde. 2006. "Governmentality." Annual Review of Law and Social Sciences 2: 83-104.

Sales, Rosemary. 2002. "The Deserving and the Undeserving? Refugees, Asylum Seekers and Welfare in Britain." Critical Social Policy 22 (3): 456-478.

Sandbrook, Dominic. 2009. "How I Failed the Citizen Test." Daily Mail [online], 19 October. Accessed May 1, 2012. http://www.dailymail.co.uk/news/article-1237054/How-I-failed-citizentest-questions-political-correctness-claim-benefits-.html\#ixzz1tcPnLWMo.

Saville, Nick. 2009. "Language Assessment in the Management of International Migration: A Framework for Considering the Issues." Language Assessment Quarterly 6 (1): 17-29.

Schaap, Andrew. 2011. "Enacting the Right to Have Rights: Jacques Rancière's Critique of Hannah Arendt." European Journal of Political Theory 10 (1): 22-45.

Tomlinson, Sally. 2008. Race and Education: Policy and Politics in Britain. Maidenhead: Open University Press.

Travis, Alan. 2012. "UK Migrants to Face 'Patriotic' Citizenship Test." The Guardian [online] 1 May. Accessed August 17, 2012. http://www.guardian.co.uk/uk/2012/jul/01/uk-migrantspatriotic-citizenship-test.

UK Border Agency. 2012a. "Citizenship Ceremonies." UK Border Agency [online]. Accessed August 21. http://www.ukba.homeoffice.gov.uk/britishcitizenship/applying/ ceremony/.

UK Border Agency. 2012b. "ESOL Course in English with Citizenship." UK Border Agency [online]. Accessed November 27. http://www.ukba.homeoffice.gov.uk/britishcitizenship/ applying/ pplicationtypes/naturalisation/kol/esol-with-citizenship/.

Van Oers, Ricky, Eva Ersbll, and Theodora Kostakopoulou. 2010. A Re-definition of Belonging? Language and Integration Tests in Europe. Leiden: Martinus Nijhoff Publishers.

Von Koppenfels, Amanda Klekowski. 2010. "Citizenship Tests Could Signal That European States Perceive Themselves as Immigration Countries." In How Liberal are Citizenship Tests? EUI Working Papers RSCAS 2010/41, edited by Rainer Bauböck and Christian Joppke, 11-15. Florence: Robert Schuman Centre for Advanced Studies.

Wells, Charles. 2008. "Act 1: Abrahams Sacrifice." In Acts of Citizenship, edited by Engin F. Isin and Greg M. Nielsen, 75-79. London: Zed Books. 